\title{
PHYTOCHEMICAL SCREENING, ANTI-MICROBIAL ACTIVITY AND SOME PHYSICO-CHEMICAL ANALYSIS OF AWOLOWO WEED (Chromoleana odorata leaf) EXTRACT
}

\author{
A. D. Oklo ${ }^{1}$, J. P. Alimi ${ }^{2}$ and E. I. Nwokedi ${ }^{1}$ \\ ${ }^{1}$ Department of Chemistry, Benue State University, PMB 102119, Makurdi, Benue, State, Nigeria \\ ${ }^{2}$ Nigerian Stored Products Research Institute, 1 Stone Road, PMB 5044, Dugbe, Ibadan, Oyo State, Nigeria
}

\begin{abstract}
This study was conducted to investigate the phytochemical composition, some physico-chemical factors and antimicrobial activity of Awolowo weed (Chromolaena odorata) collected from Benue State University Zoological garden. The leaf extract of Chromolaena odorata with different solvents (ethanol and n-hexane) were investigated. The phytochemical analysis was carried on the leaf extracts of chromolaena odorata and the result showed the presence of many active secondary metabolites such as terpenoids, steroids, flavonoids, alkaloids, saponins, tannins, phlobatannin, phenols and anthraquinones, only phlobatannin was absent in both solvent extracts. The antimicrobial activity of the Hexane extracts indicated least and highest zones of inhibition of $6.00 \mathrm{~mm}$ and $11.67 \mathrm{~mm}$ against P. aeruginosa, $5.33 \mathrm{~mm}$ and $10.67 \mathrm{~mm}$ against salmonella, $4.33 \mathrm{~mm}$ and $8.67 \mathrm{~mm}$ for E. coli. While for the ethanol extract, the least and highest zones of inhibition of $5.00 \mathrm{~mm}$ and $10.67 \mathrm{~mm}$ against P. aeruginosa, $5.00 \mathrm{~mm}$ and $10.33 \mathrm{~mm}$ against salmonella, $6.33 \mathrm{~mm}$ and $11.00 \mathrm{~mm}$ for E. coli. The ethanol extract had a specific gravity of $1.48 \mathrm{~g}$, an iodine value of $92.4 \mathrm{Wij}$ 's, the peroxide value 0.52 meq peroxide/grams of the sample, $\mathrm{pH}$ of 4.3 at $31{ }^{\circ} \mathrm{C}$ and refractive index of 1.621 at $20{ }^{\circ} \mathrm{C}$. Chromolaena odorata extract possesses antimicrobial activity and thus, represents a promising source for medicine and has enormous therapeutic potentials that can be largely explored.
\end{abstract}

Keywords: Anti-bacterial, Chromoleana odorata, leaf, Physicochemical Analysis, Benue.

\section{INTRODUCTION}

Most people are not familiar with the name of this leave Awolowo weed (chromoleana odorata) commonly called Siam weed, locally called Abokpai (Alaha kon) in Tiv, Anagwagwu in Akweya, Obukpai in Etulo and Akintola by the Yorubas.

The medicinal value of plants lies in the bioactive compounds such as alkaloids, flavonoids, tannin and phenolic compounds that produce a specific physiological action on the human body [1]. The increasing use of plant extracts in food, cosmetic and pharmacological industries suggests that in order to extract active compounds, a methodical study of medicinal plants is important [2]. Plants are major source of herbal medicines and the presence of secondary metabolites in plants concerned them for many therapeutic activities [3]. Medicinal herbs have been in use in one form or another, under indigenous systems of medicine like Ayurveda, Siddha and Unani. Various active principles have been isolated from the plants and many of them play a dominating role in the modern therapy. At present, nearly $30 \%$ or more of the modern pharmacological drugs are derived directly or indirectly from plants and their extracts govern in homeopathic or ayurvedic medicines [4].

When a new drug is introduced into clinical practice, microorganisms particularly bacteria develop resistance to such drug within short period of its introduction. In other words, new chemotherapeutic agents have always been accompanied by corresponding increase in drug resistance [5]. The problem of drug resistance has prompted researchers to turn their attentions to folk medicines as alternative to conventional chemotherapeutic agents following several reports on the medicinal opportunities derived from higher plants [6]. One of these plants is Chromolaena odorata which belong to the family Asteraceae. This weed is found in tropical Africa, North America, and South and Southeast Asia. The common names include Siam weed, Christmas bush, and common floss flower [7]. Traditional medicinal uses include anti-diarrheal, astringent, antispasmodic, antihypertensive, antiinflammatory, diuretic tonic, antipyretic and heart tonic [8]. The phytochemical components or the secondary metabolites 
(Alkaloids, Tannins, Flavonoids and other Phenolic compounds) found in this plant have medical values. Generally, plant secondary metabolites exhibit their microbial actions by disrupting membrane function and structure, interrupting DNA/RNA synthesis, interfering with intermediary metabolism, inducing coagulation of cytoplasmic constituents and interrupting normal cell communication [9].

Pocket of studies have demonstrated biological activities of plants: phytopathogenic activity [10], anthelmintic activity, antiviral activity [11] as well as antiprotozoal activity [12] to mention a few. Ijato and Tedela [13] demonstrated that $C$. odorata extract has inhibitory effect against fungal deteriorating agents of yam tubers. In addition, other authors also demonstrated that $C$. odorata extract exhibits bacterial activities and contains some phytochemicals [14]. These later authors either use water, alcohol, ester or both as solvents as well as varied susceptibility test methods (minimum inhibitory concentration or disc diffusion). In this study however, different solvent combination (ethanol and n-hexane), technique of phytochemical screening, and antibacterial method (agar well dilution) were employed to evaluate the presence of nine phytochemicals in and medicinal properties of $C$. odorata leaf extract on selected strains of microorganisms. Medicinal plants have been discovered and used in traditional medicine practices since prehistoric times.

Plants synthesis hundreds of chemical compounds for functions like defence against inescts, fungi, diseases, and herbivorous mammals. Numerous phytochemicals with potential or established biological activity have been identified. Furthermore, the phytochemical content and pharmacological actions, if any, of many plants having medicinal potential remain unassessed by rigorous scientific research to define efficacy and safety [15].

This brings to light the importance of continuous laboratory research on medicinal plants in our community so as to use them for treatment hence, improve, as well as move on from synthesized drugs which though are effective but also have their side effect to the human system. This present study or research is to evaluate the phytochemicals present in chromolaena odorata and hence, it's antimicrobial activity and some physic-chemical properties thus, providing an opportunity for pharmaceutical industries to provide us with a more accurate and more friendly drugs for the betterment of the human health. Researching into Chromolaena odorata is to come up with pertinent data on the pharmaceutical activities, antimicrobial and therapeutic values so as to be used effectively in the treatment and cure of various ailments by using them against a wide range of diseases. This will create more awareness into medically active plant leaves and will act as a data base in the medicine especially herbal medicine. Therefore, this study was conducted to assess the phytochemicals present in chromoleana odorata, physico-chemical properties as well as determining its antimicrobial activity against certain organisms.

\section{MATERIALS AND METHOD}

\subsection{Study Area}

The study was carried out in Makurdi, capital of Benue State, Nigeria. Makurdi is located at the North Eastern part of Benue State and it lies on latitude $7^{0} 30^{\prime} \mathrm{N}$ and Longitude $8^{0} 35^{\prime} \mathrm{E}$. It shares boundaries with Gwer-West and Guma Local Government Areas including Nassarawa State [16].

Makurdi lies in the tropical guinea savannah zone of central Nigeria, experiences a typical climate with two distinct seasons. The dry season lasts from late October to March and the rainy season which begins in April to October is the period of intensive agricultural activities by the inhabitants who are mostly the Tivs, Idomas, Igedes and the Jukuns. (Meteological Department, Nigeria Air force Base Makurdi, Unpublished data). The rainy season which lasts for seven months, has a mean annual rainfall ranging from 1,200-2000mm. High temperature values averaging $28^{0} \mathrm{C}-33^{\circ} \mathrm{C}$ are recorded in Makurdi throughout the year, most notable from March to April. Harmattan winds are accompanied with cooling effects mostly during the night of December and January [17].

\subsubsection{Sample Collection}

The leaves of chromolaena odorata were collected on the $6^{\text {th }}$ of November, 2018 at Zoology garden of Benue State University Makurdi, in Benue State. They were authenticated by a botanist of Biological Sciences of Benue State University Makurdi.

\subsubsection{Sample Preparation}

The leaves of chromolaena odorata were air dried at room temperature dried for two weeks, after which they were crushed into fine powder by using a clean wooden mortar and pestle which was followed by sieving using a mm mesh wire or plastic sieve so as to completely remove coarse particles. The fine powdered materials were then stored in an air tight poly-ethene bags and kept for further analysis. 


\subsection{Materials and Chemical Reagent}

Mortar and Pestle, Conical flask, Beaker, Measuring cylinders, Soxhlet apparatus, Water bath, Boiling chips, Filter papers, Test tubes and their holders, Spatula, Mesh cloth, Tripod stand, Bunsen burner, Incubator, Solvent tanks, Petri dishes, Auto clave, Capillary tube, Inoculation wire loop, Funnels, Syringes, Culture plates, Oven, Refrigerator, Condenser. Chemical reagent used includes Fehling solutions (A and B), Methanol, n-Hexane, Distilled water, Ferric chloride 3.5\% (3.5mL of $\mathrm{FeCl}_{3}$ in $96.5 \mathrm{~mL}$ of solvents), Dilute tetraoxosulphate (IV) acid $\left(\mathrm{H}_{2} \mathrm{SO}_{4}\right)$, Sodium hydroxide $(\mathrm{NaOH})$, Zinc chips, Meyer's reagent, Dragendoff's reagent, Ammonia, Chloroform $\left(\mathrm{CHCl}_{3}\right)$, Nutrient agar, Ethyl acetate, Acetone, Aqueous hydrochloric acid $(1 \% \mathrm{HCl})$, Ethanol, Benzene.

\subsubsection{Extraction Process (Soxhlet Extraction)}

The solvents used for the extraction were $n$-hexane and methanol

\subsubsection{Hexane extraction}

Exactly $30.0 \mathrm{~g}$ of the powdered sample was weighed and poured into a white handkerchief and sealed properly. $300 \mathrm{~mL}$ of $\mathrm{n}$ hexane was measured and carefully poured into the soxhlet extractor connected to the round bottom flask. Boiling chips were placed in the flask to prevent superheating. The soxhlet extractor fitted unto the round bottom flask was mounted on a heating mantle supported by a retort stand. The set up was heated for 6 hours to ensure complete extraction using distilled column. The crude extract in the round bottom flask was heated in a water bath to concentrate the solvent. The crude extract was then transferred into an already weighed plastic container and allowed to evaporate to dryness. The concentrated extract was then kept for further analysis.

\subsubsection{Methanol extraction}

About $30.0 \mathrm{~g}$ of the powdered sample weighed and transferred into a white handkerchief and sealed properly. $300 \mathrm{~mL}$ of methanol was measured and used for extraction. The procedure was the same as the one in the extraction with n-hexane.

\subsection{Phytochemical Screening}

Phytochemical screening of the leaf extract of chromolaena odorata was carried out to determine the phytochemicals present in the plant using standard methods [18].

\subsubsection{Test for saponins (Frothing tests)}

Exactly $0.5 \mathrm{~g}$ of the extract was shaken vigorously with $10 \mathrm{~mL}$ of distilled water in a test tube. Frothing which persist on warming indicates the presence of saponins.

\subsubsection{Test for tannins (Braymer's test)}

About $2 \mathrm{~mL}$ of extract was treated with $2 \mathrm{~mL}$ of distilled water and 2-3 drops of $5 \%$ ferric chloride and shaken. Greenish precipitate indicates the presence of tannins

\subsubsection{Test for alkaloids (Mayer's test)}

About $0.2 \mathrm{~mL}$ of concentrated hydrochloric acid was added to $2 \mathrm{~mL}$ of aqueous solution of the crude extract. Then, $1 \mathrm{~mL}$ of Mayer's reagent was added. Formation of yellow colour precipitate indicates the presence of alkaloids.

\subsubsection{Test for flavonoids (Alkaline reagents test)}

Exactly $2 \mathrm{~mL}$ of extracts was treated with few drops of $20 \%$ sodium hydroxide solution. Formation of intense yellow colour, which becomes colourless on addition of dilute hydrochloric acid, indicates the presence of flavonoids.

\subsubsection{Test for steroids (Salkowski's test)}

About $2 \mathrm{~mL}$ of the extracts was treated with methyl trichloride and $2 \mathrm{~mL}$ of concentrated sulphuric acid, reddish brown ring at the junction indicates the presence of steroids.

\subsubsection{Test for terpenoids (Salkowski's test)}

About $1 \mathrm{~mL}$ of chloroform was added to $2 \mathrm{~mL}$ of extract followed by a few drops of concentrated sulphuric acid. A reddish brown precipitate produced immediately indicates the presence of terpenoids. 
International Journal of Advances in Scientific Research and Engineering (ijasre), Vol 5 (9), September-2019

\subsubsection{Test for phenols (Ferric chloride test)}

A fraction of the extract was treated with aqueous $5 \%$ ferric chloride and observed for the formation of deep blue or black colour.

\subsubsection{Test for phlobatannins}

About $1 \mathrm{~mL}$ of the extract was transferred into a $5 \mathrm{ml}$ test tube, add a few drops of $1 \%$ hydrochloric acid and boil. A red precipitate indicates the presence of phlobatannins.

\subsubsection{Test for anthraquinones (Borntrager's test)}

The crude extract was shaken with $15 \mathrm{~mL}$ of benzene. This was filtered and $5 \mathrm{~mL}$ of $10 \%$ ammonia solution was added to the filtrate. On shaking it was observed that there was a pink, violet or red colour in the ammoniacal layer indicating the presence of anthraquinone.

\subsection{Antibacterial Activity of the Fraction}

\subsubsection{Preparation of culture medium}

$8.4 \mathrm{~g}$ of the nutrient agar were weighed and dissolved in $250 \mathrm{~mL}$ of distilled water. The mixture was sterilized in an autoclave at $121^{\circ} \mathrm{C}$ for 15 minutes. After that, the mixture was removed from the autoclave and was allowed to cool to $45^{\circ} \mathrm{C}$ and then poured into petri dishes and allowed to gel. The bacterium already cultured were dissolved in $0.9 \%$ normal saline solution as the diluents and gentamycin as the positive control [19].

\subsubsection{Preparation of extracts solution}

$1 \mathrm{~g}$ of the $\mathrm{n}$-hexane extracts of both plants were weighed and dissolved in $100 \mathrm{~mL}$ of distilled water to give the full strength. $1 \mathrm{~mL}$ of the solution was pipette and dissolved in $5 \mathrm{~mL}$ of distilled water to give the second dilution. $1 \mathrm{~g}$ of the methanol extracts of the plant were weighed and dissolved in $100 \mathrm{~mL}$ of distilled water to give the full strength solution. The serial dilution was repeated as in the case of the hexane extracts of both plants above. This method is known as disc diffusion method [19].

\subsubsection{Inoculation and sensitivity test}

Each of the plants extracts were prepared in the ratio $1 ; 10$ which is equivalent to $100 \mathrm{mg} / \mathrm{mL}$. holes were dug in the nutrient agar medium in the petri dishes $0.2 \mathrm{~mL}$ of the $1 ; 10$ dilution was dispersed into the hole in the nutrient agar medium making a concentration of $10 \mathrm{mg}$ per hole. Before inoculation, the four different micro organisms Staphylococcus aureus (gram positive bacteria), salmonella typhi (gram negative bacteria), escherichia coli (gram negative bacteria) were smeared separately using swap sticks on different petri dishes after which each extract solution were introduced and the petri dishes were incubated for 24 hours the petri dishes were removed and zone of the inhibition was measured for each organism in both of the extract solutions [19].

\subsection{Physico-chemical Tests}

\subsubsection{Determination of Specific Gravity}

A clean empty $50 \mathrm{~mL}$ density bottle was weighed, then filled with distilled water $\left(\mathrm{H}_{2} \mathrm{O}\right)$ and weighed again with the water inside it. The bottle was then emptied, dried, then filled with the Chromoleana odorata leaves extract and the weight of the bottle containing the oil was determined using an electronic weighing machine.

\subsubsection{Determination of the oil's refractive index}

The refractive index of the extracted oil was determined with an Abbe refractometer (an Abbe 60/DR refractometer) at $20^{\circ} \mathrm{C}$ after which the refractive index of the Chromoleana odorata leaves extract was taken. A drop of Chromoleana odorata leaves extract was spotted on the glass slide of the refractometer connected to a light source. The temperature adjuster was used to adjust the temperature, and the refractometer was viewed through the monitoring glass space to take the scale reading, which was the refractive index of the sample.

\subsubsection{Determination of the iodine value of the Chromoleana odorata leaves extract}

About $0.25 \mathrm{~g}$ of Chromoleana odorata leaves extract was weighed accurately into a $250 \mathrm{~mL}$ conical flask. $10 \mathrm{~mL}$ of carbon tetrachloride $\left(\mathrm{CCl}_{4}\right)$ was transfered into the flask to dissolve the Chromoleana odorata leaves extract. $10 \mathrm{~mL}$ of Wij's solution measured was added, and the flask was stoppered. The mixture was swirled properly and allowed to stand in the dark for 
30minutes. $7.5 \mathrm{~mL}$ of $10 \% \mathrm{~K} 1$ solution and $50 \mathrm{~mL}$ of distilled water was added. The mixture was then titrated with a $0.1 \mathrm{M}$ $\mathrm{Na}_{2} \mathrm{~S}_{2} \mathrm{O}_{3 \cdot 5} \mathrm{H}_{2} \mathrm{O}$ solution using a $1 \%$ starch indicator just before the end point. The blank was carried out using similar procedure without the Chromoleana odorata leaves extract.

\subsubsection{Determination of the peroxide value of the Chromoleana odorata leaves extract}

About $2 \mathrm{~g}$ of Chromoleana odorata leaves extract was weighed accurately into a $250 \mathrm{~mL}$ conical flask. $30 \mathrm{~mL}$ Acetic acid and 20 $\mathrm{mL}$ of carbon tetrachloride $\left(\mathrm{CCl}_{4}\right)$ was transfered into the cornical flask containing the Chromoleana odorata leaves extract. The mixture was swirled properly and allowed to stand in the dark for 5 minutes. $0.5 \mathrm{~mL}$ of $10 \% \mathrm{~K} 1$ solution and $30 \mathrm{~mL}$ of distilled water was added. The mixture was then titrated with a $0.1 \mathrm{M} \mathrm{Na}_{2} \mathrm{~S}_{2} \mathrm{O}_{3 \cdot 5} \mathrm{H}_{2} \mathrm{O}$ solution using a starch solution as indicator just before the end point. The blank was carried out using similar procedure without the Chromoleana odorata leaves extract.

\subsubsection{Determination of $\mathrm{pH}$}

The solution of Chromoleana odorata leave extract was transferred into a $100 \mathrm{~mL}$ volumetric flask and made up to the mark using distilled water. A pH meter was incorporated into the solution using a glass cell and reference electrode.

\section{RESULTS}

The results of phytochemical screening tests of both Ethanol and n-Hexane extract were tabulated as shown in Table 1.

Table 1: Result of Phytochemical Screening Tests of both Ethanol and n-Hexane Extract

\begin{tabular}{|c|c|c|}
\hline Tests & Ethanol & n-Hexane \\
\hline Saponins & + & + \\
\hline Tannins & + & + \\
\hline Alkaloids & + & + \\
\hline Flavonoids & + & + \\
\hline Steroids & + & + \\
\hline Terpenoids & + & + \\
\hline Phenol & + & + \\
\hline Phlobatannins & + & + \\
\hline Anthraquinones & & + \\
\hline
\end{tabular}

The results of physico-chemical test of ethanol extract were tabulated as shown in Table 2.

Table 2: Table Showing Results of Physico-Chemical Test of Ethanol Extract

\begin{tabular}{|c|c|}
\hline Tests & Values \\
\hline pH Test & 4.30 at $31{ }^{\circ} \mathrm{C}$ \\
\hline Refractive Index & 1.621 at $20^{\circ} \mathrm{C}$ \\
\hline Specific Gravity & 1.48 \\
\hline Iodine Value & 92.4 Wij's \\
\hline Peroxide Value & 0.52 meq peroxide/grams \\
\hline
\end{tabular}

The results of the mean inhibitory effect of hexane extract on the test organisms were tabulated as shown in Table 3. The result of the inhibitory effect of hexane extract in this study shows that the plant extract was active against all the test organisms.

Table 3: The Mean Inhibitory Effect of Hexane Extract on the Test Organisms

\begin{tabular}{|c|c|c|c|}
\hline Concentration & \multicolumn{3}{|c|}{ Zones of Inhibition (mm) } \\
\hline & Samonella & S. aureus & E. coli \\
\hline $100 \mathrm{mg} / \mathrm{mL}$ & 10.67 & $11.67^{\mathrm{b}}$ & $7.07^{\mathrm{de}}$ \\
\hline $50 \mathrm{mg} / \mathrm{mL}$ & $7.67^{\mathrm{a}}$ & $10.33^{\mathrm{b}}$ & $5.33^{\mathrm{ef}}$ \\
\hline $25 \mathrm{mg} / \mathrm{mL}$ & $6.33^{\mathrm{a}}$ & $7.33^{\mathrm{c}}$ & $4.33^{\mathrm{f}}$ \\
\hline $12.5 \mathrm{mg} / \mathrm{mL}$ & $5.33^{\mathrm{a}}$ & $6.00^{\mathrm{c}}$ & $\mathbf{1 . 6 4}$ \\
\hline HSD $(\mathbf{P}<\mathbf{0 . 0 5})$ & $\mathbf{1 . 0 0}$ & $\mathbf{0 . 4 1}$ & \\
\hline
\end{tabular}

Means tagged with the same alphabets are not significant 
The results of the mean inhibitory effect of ethanol extract of Chromoleana odorata on the test organisms were tabulated as shown in Table 4. The result of the Mean inhibitory effect of the ethanol extract of Chromoleana odorata shows that the plant extract has antibacterial activity on the test organisms as shown in Table 4.

Table 4: The Mean Inhibitory Effect of Ethanol Extract of Chromoleana odorata on the Test Organisms

\begin{tabular}{|c|c|c|c|}
\hline Concentration & \multicolumn{3}{|c|}{ Zones of Inhibition (mm) } \\
\hline & Samonella & S. aureus & E. coli \\
\hline $100 \mathrm{mg} / \mathrm{mL}$ & 10.33 & $10.67^{\mathrm{c}}$ & 8.00 \\
\hline $50 \mathrm{mg} / \mathrm{mL}$ & $7.00^{\mathrm{a}}$ & $9.33^{\mathrm{c}}$ & $7.33^{\mathrm{e}}$ \\
\hline $25 \mathrm{mg} / \mathrm{mL}$ & $6.33^{\mathrm{ab}}$ & $6.33^{\mathrm{d}}$ & $6.33^{\mathrm{e}}$ \\
\hline $12.5 \mathrm{mg} / \mathrm{mL}$ & $5.00^{\mathrm{b}}$ & $5.00^{\mathrm{d}}$ & $\mathbf{1 . 6 4}$ \\
\hline HSD $(\mathbf{P}<\mathbf{0 . 0 5})$ & $\mathbf{1 . 0 0}$ & $\mathbf{0 . 4 1}$ & \\
\hline
\end{tabular}

Means tagged with the same alphabets are not significant

The results of the mean inhibitory effect of the control on the test organisms were tabulated as shown in Table 5. The antibiotic used as control in this study had potent effect on all the test organisms at all concentrations. This is shown in table 5 .

Table 5: The Mean Inhibitory Effect of the Control on the Test Organisms

\begin{tabular}{|c|c|c|c|}
\hline Concentration & \multicolumn{3}{|c|}{ Zones of Inhibition $(\mathbf{m m})$} \\
\hline & Samonella & S. aureus & E. coli \\
\hline $40 \mathrm{mg} / \mathrm{ml}$ & $19.67^{\mathrm{a}}$ & 23.33 & 23.67 \\
\hline $20 \mathrm{mg} / \mathrm{ml}$ & $18.33^{\mathrm{a}}$ & 22.00 & 20.00 \\
\hline $10 \mathrm{mg} / \mathrm{ml}$ & $16.67^{\mathrm{b}}$ & 19.67 & 18.00 \\
\hline $5 \mathrm{mg} / \mathrm{ml}$ & $15.33^{\mathrm{b}}$ & 17.67 & $\mathbf{1 . 0 0}$ \\
\hline HSD $(\mathbf{P}<\mathbf{0 . 0 5})$ & $\mathbf{0 . 8 5}$ & $\mathbf{1 . 0 0}$ & \\
\hline
\end{tabular}

Means tagged with the same alphabets are not significant

The results of the comparative mean inhibitory effect of the extracts (Ethanol and Hexane) of Chromoleana odorata and the control on the test organisms were tabulated as shown in Table 6. The comparative analysis of the extracts (Hexane and Ethanol) of Chromoleana odorata and the antibiotic used as control shows that the antibiotic had higher effect on all the test organisms compared with the hexane and ethanol extracts of the plant at $\mathrm{P}<0.05$.

Table 6: The Comparative Mean Inhibitory Effect of the Extracts (Ethanol and Hexane) of Chromoleana odorata and the Control on the Test Organisms

\begin{tabular}{|c|c|c|c|c|}
\hline Extract & \multicolumn{3}{|c|}{ Zones of Inhibition (mm) } & HSD (P<0.05) \\
\hline & Samonella & S. aureus & E. coli & \\
\hline Hexane & $10.67^{\text {ab }}$ & $11.67^{\mathrm{c}}$ & 11.00 & $\mathbf{0 . 4 0 8}$ \\
\hline Ethanol & $10.33^{\mathrm{b}}$ & $10.67^{\mathrm{c}}$ & $23.67^{\mathrm{d}}$ & $\mathbf{N S}$ \\
\hline Control & 19.67 & $23.33^{\mathrm{d}}$ & $\mathbf{1 . 0 0}$ & \\
\hline HSD $(\mathbf{P}<\mathbf{0 . 0 5})$ & $\mathbf{1 . 0 0}$ & $\mathbf{1 . 0 0}$ & $\mathbf{1 . 0 0}$ & \\
\hline
\end{tabular}

Means tagged with the same alphabets are not significant

NS: Not Significant

\section{DISCUSSION}

The preliminary phytochemical screening of Chromolaena odorata leaves showed the presence of various secondary metabolites including alkaloids, tannins, flavonoids, saponins etc as shown in Table 1. Phytochemical analysis of Chromolaena odorata leaves showed that it contains alkaloids, flavoloids, saponins, tannins, terpenoids, anthraquinone, phenol and steroids (Table 1). The presence of secondary metabolites such as alkaloids, saponins, tannins, flavonoid will contribute to its medicinal value (example in healing open wounds). Terpenoids and phenols were fairly present both in ethanolic and n-hexane extract. Meanwhile saponins were fairly present on ethanolic extract but were totally absent on n-hexane extract while Phlobatannins were totally absent in both extracts. 
It is imperative to note that the type of solvent used during extraction has a significant effect on the diversity of compound in the plant extract. Earlier reports from [20] indicated that the polarity of a solvent plays an important role in solubility of target phytochemicals. Methanol is more polar than ethyl-ether, and this might be responsible for the observed variation in different. The presence of terpenoids (a volatile oil) in this study was previously documented on its effect on plant, fungi and plant growth [21]. The detection of phenolics, alkaloids, steroids, saponins, flavonoids and tannins in $C$. odorate leaf was also comparable to similar studies by different authors [22]. However, flavonoids and phenolics were not detected by other authors [23]. The abundance phytochemicals in this extract (terpenoids, steroids, alkaloids and anthraquinones) may probably be linked to its importance in protective function, physical characteristics and chemical characteristics of $C$. odorata plant. Phytochemicals protect plants from disease and damage, environmental hazards such as pollution, stress, drought, UV exposure and pathogenic attack as well as contribute to the plant's color, aroma and flavor [24].

The $\mathrm{pH}$ value was found to be 4.30 at $31{ }^{\circ} \mathrm{C}$, Iodine value of $92.4 \mathrm{Wij}$ 's indicating a certain degree of unsaturation. Iodine numbers are often used to determine the amount of unsaturation in fatty acids. This unsaturation is in the form of double bonds, which react with iodine compounds. The higher the iodine number, the more $\mathrm{C}=\mathrm{C}$ bonds are present in the fat [25]. While the refractive index value was obtained to be 1.621 at $20{ }^{\circ} \mathrm{C}$, since refractive index is a fundamental physical property of a substance, it is often used to identify a particular substance, confirm its purity, or measure its concentration. Refractive index is used to measure solids, liquids, and gases. Most commonly it is used to measure the concentration of a solute in an aqueous solution. In optics, the refractive index or index of refraction of a material is a dimensionless number that describes how fast light propagates through the material [26].

Specific gravity of 1.48 , which is the ratio of the density of a substance to the density of a reference substance; equivalently, it is the ratio of the mass of a substance to the mass of a reference substance for the same given volume. It specific gravity is higher than that of water 1 but less than that of iron wood 1.5 [27]. And has peroxide value of 0.52 milliequivalents $/ \mathrm{kg}$, peroxide value is the amount of peroxide oxygen per 1 kilogram of fat or oil, when the peroxide value is between 30 and 40 milliequivalents $/ \mathrm{kg}$, a rancid taste is noticeable, hence $C$. odorata has a good peroxide value.

The result of the inhibitory effect of hexane extract shows that the plant extract was active against all the test organisms (Table 3). The highest zone of inhibition $(10.67 \mathrm{~mm})$ for Salmonella was observed at $100 \mathrm{mg} / \mathrm{ml}$ and this was statistically significant when compared with the effect at the other concentrations at $\mathrm{P}<0.05$. There was no statistical significance $(\mathrm{P}>0.05)$ when the effect was compared at the other concentrations. The highest zone of inhibition was also observed for S. aureus at $100 \mathrm{mg} / \mathrm{ml}(11.67 \mathrm{~mm})$ of the hexane extract. The effect was statistically insignificant when compared with the effect at $50 \mathrm{mg} / \mathrm{ml}(10.33 \mathrm{~mm})$ at $\mathrm{P}>0.05 \mathrm{but}$ also was significant when compared with the effect at the lower concentrations at $\mathrm{P}<0.05$. The effect at $25 \mathrm{mg} / \mathrm{ml} \mathrm{and} 12.5 \mathrm{mg} / \mathrm{ml}$ was insignificant $(\mathrm{P}>0.05)$ when compared. The highest zone of inhibition for E. coli was observed at $100 \mathrm{mg} / \mathrm{ml}(8.67 \mathrm{~mm})$. When the effect was compared with the effect at $50 \mathrm{mg} / \mathrm{ml}$, it was insignificant at $\mathrm{P}>0.05$ but significant when compared with the other lower concentrations $(\mathrm{P}<0.05)$. The effect at $50 \mathrm{mg} / \mathrm{ml}$ was not significant compared with $25 \mathrm{mg} / \mathrm{ml}$ (P>0.05) but significant compared with $12.5 \mathrm{mg} / \mathrm{ml}$. The effect at $25 \mathrm{mg} / \mathrm{ml}$ and $12.5 \mathrm{mg} / \mathrm{ml}$ when compared however, was insignificant at $\mathrm{P}>0.05$.

The result of the Mean inhibitory effect of the ethanol extract of Chromoleana odorata shows that the plant extract has antibacterial activity on the test organisms (Table 4). The highest effect for Salmonella seen at 100mg/ml (10.33) was significant when compared with other concentrations at $\mathrm{P}<0.05$. The effect at $50 \mathrm{mg} / \mathrm{ml}$ and $25 \mathrm{mg} / \mathrm{ml}$ was insignificant $(\mathrm{P}>0.05)$ when compared with each other. While the effect at $50 \mathrm{mg} / \mathrm{ml}$ was significant when compared with the effect at $12.5 \mathrm{mg} / \mathrm{ml}(\mathrm{P}<0.05)$, it was insignificant at $25 \mathrm{mg} / \mathrm{ml}$ when compared with $12.5 \mathrm{mg} / \mathrm{ml}$ at $\mathrm{P}>0.05$. The zone of inhibition for $S$. aureus was higher at $100 \mathrm{mg} / \mathrm{ml}$ but its effect was statistically insignificant compared with $50 \mathrm{mg} / \mathrm{ml}$ at $\mathrm{P}>0.05$ but significant at $\mathrm{P}<0.05$ when compared with the effect at lower concentrations. The effect at $25 \mathrm{mg} / \mathrm{ml}$ and $12.5 \mathrm{mg} / \mathrm{ml}$ when compared, was not statistically significant (P>0.05). The highest effect on E. coli was at $100 \mathrm{mg} / \mathrm{ml}$ which was significant when compared with the other concentrations at $\mathrm{P}<0.05$. The effect at $25 \mathrm{mg} / \mathrm{ml}$ when compared with $12.5 \mathrm{mg} / \mathrm{ml}$ was however not significant $(\mathrm{P}>0.05)$.

The antibiotic used as control in this study had potent effect on all the test organisms at all concentrations (Table 5). The highest zone of inhibition for Salmonella was $19.67 \mathrm{~mm}$ at $40 \mathrm{mg} / \mathrm{ml}$ whose effect was insignificant compared with $20 \mathrm{mg} / \mathrm{ml}(\mathrm{P}>0.05)$ but significant compared with $10 \mathrm{mg} / \mathrm{ml}$ and $5 \mathrm{mg} / \mathrm{ml}$ at $\mathrm{P}<0.05$. The effect at $20 \mathrm{mg} / \mathrm{ml}$ and $5 \mathrm{mg} / \mathrm{ml}$ was insignificant when compared $(\mathrm{P}>0.05)$ respectively. The effect of this control on $S$. aureus and E.coli increased significantly from the lowest to the highest concentration used in this study at $\mathrm{P}<0.05$.

The comparative analysis of the extracts (Hexane and Ethanol) of Chromoleana odorata and the antibiotic used as control shows that the antibiotic had higher effect on all the test organisms compared with the hexane and ethanol extracts of the plant at $\mathrm{P}<0.05$ 
(Table 6). The highest effect of the antibiotic was observed on E. coli and this was significant when compared with Salmonella at $\mathrm{P}<0.05$ but insignificant when compared with $S$. aureus at $\mathrm{P}>0.05$.

The effect of hexane extract on Salmonella and $S$. aureus was insignificant when compared with the effect of the ethanol extract on them $(\mathrm{P}>0.05)$ while ethanol extract had higher effect on $E$. coli than the hexane extract at $\mathrm{P}<0.05$. The effect of the hexane extract was higher on $S$. aureus compared to $E$. coli $(\mathrm{P}<0.05)$ but not significant when compared with Salmonella $(\mathrm{P}>0.05)$. Its effect on Salmonella was however not significant when compared with E. coli at $\mathrm{P}>0.05$. The inhibitory activity of the ethanol extract of the leaf of $C$. odorata on E. coli and S. aureus is compatible with the findings [28], but disagrees on the actibacterial activity of hexane extract which no inhibitory effect was observed in their study. However, their work was carried out in Thailand where the plants for the studies differ in origin, topography and climate. According to [29], the quality of plant extracts is generally affected by factors such as the nature of the plant material (season, topography and climate) and its origin (locations). The type of solvent used in the extraction procedure also plays important role in the diversity of compounds in the plant extracts. The zone of inhibition for the ethanol extract was higher for the E. coli; but this was insignificant when compared with the effect on the other two bacterial isolates at $\mathrm{P}>0.05$

The antibacterial activities of both hexane and ethanol leaf extracts of $C$ odorata on the studied bacterial isolates can be attributed to the presence of secondary metabolites produced by this plant. Apart from the odors, flavors and colors of plants, the presence of some phytochemicals determines the antimicrobial properties of any plant and define their defense systems or resistance against some pathogen [30]. Generally, plant secondary metabolites exhibit their microbial actions by disrupting membrane function and structure, interrupting DNA/RNA synthesis, interfering with intermediary metabolism and inducing coagulation of cytoplasmic constituents [31,32]. As such, Since the extract has different phytochemicals of varied concentrations, high activity of the extract may be attributed to synergistic effects of the various phytochemicals present in the leaf extract of this plant.

Several antimicrobial studies of this plant had reported its activities on bacteria. [33] reported the potent activity of this plant extract against two species of Staphylococcus (S. aureus and S. epidermidis) in their study. [34] reported its antibacterial activity against S. aureus, E. coli and P. aeruginosa; while [35] reported its activity against Neisseria gonorrhoea respectively. Good inhibition with the leaf extract of $C$. odorata in the study of some selected microorganisms such as Escherichia coli, Enterococcus faecalis, Pseudomonas aeruginosa, Enterococcus cloacae and Klebsiella pneumonia was also reported by [36]. Also [37] in their study of the antimicrobial activity of $C$. odorata reported its antibacterial activity against selected pyogenic pathogens which $P$. aeruginosa was one of them.

\section{CONCLUSION}

Chromolaena odorata extract possesses antimicrobial activity and thus, represents a promising source for medicines of which when carefully tapped and explored has enormous therapeutic potentials. It is also important to note that while herbal-derived medicines may be an alternative for combating microbial infections, care should be taken to minimize the risk associated with them. In conclusion, this study provides a scientific basis for further testing and characterization of the medicinal properties of individual compounds from Chromolaena odorata leaves. Further research should be carried out to enhance knowledge on the therapeutic potentials, medicinal properties and (as locally known) healing power of C. ododrata.

\section{ACKNOWLEDGMENTS}

This work was supported by the Department of Chemistry, Benue State University.

\section{REFERENCES}

[1] A.F. Hill, (1952). Economic Botany. A textbook of useful plants and plant products. 2 nd edition. McGraw-Hill Book Incorporated Company, New York.

[2] k. S. Arun, M. Muthuselvam, and R. Rajasekaran, Analysis of Phytochemical constituents and antimicrobial activity of some Southern Indian medicinal plants, Journal of Pharmaceutical Research, Vol. 3(8), 2010, Pages 1841-1843.

[3] K. Sachin, S. C. Hotam, and S. Chandrabhan, In vitro antibacterial study of aqueous and methanolic extracts of some selected medicinal plants, Journal of Chemicals Pharmaceutical Research, Vol. 3(4), 2011, Pages 854-860.

[4] S. Murugesan, A. Pannerselvam, and A.C. Tangavelu, Phytochemical screening and antimicrobial activity of the leaves of Memecylo umbellatum burm, F. Journal of Applied Pharmaceutical Science, Vol. 1, 2011, Pages 42-45.

[5] G. F. Gislene, N.J. Locatelli, C.F. Paulo, and L.S. Giuliana, Antibacterial activity of plant extracts and phytochemicals on antibiotic resistant bacteria, Brazil Journal of Microbiology, Vol. 31, 2000, Pages 247-256. 
[6] L.P. Santos Pimenta, G.B. Pinto, J.A. Takahashi, L.G. Silva, M.A. Boaventura, Biological screening of annonaceous Brazilian medicinal plants using Artemia salina L. (Brine Shrimp Test). Phytomedicine journal, Vol. 10(2-3), Mar 2003, 209-212.

[7] A.K. Chakraborty, S. Rambhade, Patil, UK. Chromolaena odorata (L.): An overview. Journal of Pharmaceutical Research. Vol. 4(3), 2011, Pages 573-576.

[8] A. Suksamrarn, A. Chotipong, T. Suavansri, S. Boongird, P. Timsuksai, S. Vimuttipong, A. Chuaynugul Antimycobacterial activity and cytotoxicity of flavonoids from the flowers of Chromolaena odorata, Arch Pharmaceutical Research, 2004, Pages 507-511.

[9] N.S. Radulovic, P.D. Blagojevic, Z.Z. Stojanovic-Radic, N.M. Stojanovic, Antimicrobial plant metabolites: Structural diversity and mechanism of action, Current Medicine in Chemistry, Vol. 20(7), 2013, Pages 933-951.

[10] S.L. Sukanya, J. Sudisha, P. Hariprasad, S.R. Niranjana, H.S. Prakash, S.K. Fathima. Antimicrobial activity of leaf extracts of Indian medicinal plants against clinical and phytopathogenic bacteria, African Journal of Biotechnology, Vol. 8(23), 2009, Pages 6677-6682.

[11] S. Pisutthanan, P. Plianbangchang, N. Pisutthanan, S. Ruanruay, O. Muanrit Brine shrimp lethality activity of Thai medicinal plants in the family Meliaceae. Naresuan, University Journal, Vol. 12, 2004, Pages 13-18.

[12] P.G. Vital, L.R. Windell Antimicrobial activity and cytotoxicity of Chromolaena odorata (L. f.) King and Robinson and Uncaria perrottetii (A. Rich) Merr. Extracts, Journal of Medical Plants Research, Vol. 3(7), 2009, Pages 511-518.

[13] J.Y. Ijato, P.O. Tedela Phytotoxic potentials of cold and hot aqueous extracts of Chromolaena odorata against fungal deteriorating agents of yam tubers (Dioscorea rotundata, Poir) after harvest, American Journal of Agriculture, Vol. 5(3), 2015, Pages 262-266.

[14] R.N. Okigbo, A.N. Ajalie, Inhibition of some human pathogens with tropical plants extracts (Chromolaena odorata and Citrus aurantifolia and some antibiotic), International Journal of Molecular Medicine in Advanced Sciences, Vol. 1(1), 2005, Pages 34-40.

[15] K. Ahn, "The worldwide trend of using botanical drugs and strategies for developing global drugs". BMB Reports. Vol. 50 (3): 2017, Pages 111-116.

[16] E. Amuta, R. Moumson, S. Mker Impact of demographic and economic factor on the prevalence of intestinal parasites among the female gender in Makurdi, Nigeria. The internet journal of third world medicine. Vol. 8 No 2, 2008.

[17] J.L. Nyangba, The Geography of Benue State: A Benue Compendium Rapid Educational Publishers Ltd, Calabar. 1995, Pp 85-87.

[18] Y. Manjulika, C. Sanjukta, and K. Sharad, Preliminary phytochemical screening of some medicinal plants used in Traditional medicine. $1^{\text {st }}$ edition. Mumbai press, India, 2015, 1-50

[19] Asue V. Phytochemical Screening of Ficus Umbellata Etracts (unpublished project), Department of Chemistry, Benue State University Makurdi, 2014.

[20] M. Naczk, F. Shahidi, Phenolics in cereals, fruit and vegetables: Occurrence, extraction and analysis, J. Pharm Biomed Ana, Vol. 41, 2006, Pages 1523-1542.

[21] Y.Y. Sheng, T.X. Bao Chemical composition of volatile oil from Chromolaena odorata and its effect on plant, fungi and insect growth, Vol. 14(5), 2003, Pages 744-7446.

[22] S. Hanphakphoom, and S. Krajangsang Antimicrobial activity of Chromolaena odorata extracts against bacterial human skin infections. Mod Appl Sc, Vol. 10(2): 2016, Pages 1913-1844.

[23] G.N. Anyasor, D.A. Aina, M. Olushola, A.F. Aniyikaye Phytochemical constituent, proximate analysis, antioxidant, antibacterial and wound healing properties of leaf extracts of Chromolaena odorata. Ann. Biol. Res, Vol. 2(2), 2011, Pages 441-451.

[24] K.C. Mondal, D. Bhargava, J.N. Shivapuri, S. Kar In vitro antigonorrhoeal activity and extraction of chemical constituents from the leaves of Chromolaena odorata (Lin.) locally known as 'BANMARA'. Int J. Chem. An. Sc, Vol. 3(7), 2012, Pages 1487-1495.

[25] Thomas, Alfred (2002). "Fats and Fatty Oils". Ullmann's Encyclopedia of Industrial Chemistry. Weinheim: Wiley-VCH.

[26] Attwood, David, Soft X-rays and extreme ultraviolet radiation: principles and applications, 1999 , p. 60.

[27] Table of liqueurs Specific Gravity. 
[28] H. Srisuda, T. Suchada, W. Piyaporn, K. Niwat and K. Sukhumaporn Antimicrobial Activity of Chromolaena odorata Extracts against Bacterial Human Skin Infections. Modern Applied Science, Vol. 10, No. 2, 2016, Pages 159-171.

[29] P. Tiwari, B. Kumar, M. Kaur, G. Kaur, and H. Kaur Phytochemical screening and extraction: A review. International Pharmaceutica Sciencia, Vol. 1(1), 2011, Pages 98-106.

[30] M.E. Osman, A.A. Magdy, M.S. El-Sayed, M.A. Walaa, and A.S. Emad, Study of antimicrobial efficacy of some plant extracts against oral pathogens and comparative analysis of their efficiency against commercially available toothpastes and mouth rinses. J. der PharmazieForschung, Vol. 2(4), 2014, Pages 6-19.

[31] P.G. Vital, and W.L. Rivera, Antimicrobial activity and cytotoxicity of Chromolaenaodorata (L. f.) King and Robinson and Uncariaperrottetii (A. Rich) Merr. extracts. Journal of Medicinal Plants, Vol. 3(7), 2009, Pages 511518

[32] A.K. Kumar, S. BinduPriya, C. Sravani, K. Amrutha Sai, S. Poornodaya, and N.R. Reddy, Comparitative evaluation of antibacterial efficacy of herbal extracts and mouth washes against subgingival plaque bacteria. An In vitro study. Journal of Dental Herbs, Vol. 1(1), 2014, Pages 1-6

[33] A.K. Nurul Huda, A.S. Mamat, A.W.M. Effendy, Z.M Hussin, and S.M.Z. Hassan, , The antimicrobial effect of Chromolaena odorata extrat on gram-positive bacteria. $11^{\text {th }}$ Internationa Conference of the Association of Institutions for Tropical Verterinary Medicine and $16^{\text {th }}$ Verterinary Association. Malaysia Congress, 2004, Pages 342-343.

[34] O.N. Irobi, Activities of Chromolaena odorata (Compositae) leaf extract against Pseudomonas aeruginosa and Streptococcus faecalis. Journal of Ethanopharma, 37, 1992, Pages 81-83.

[35] A. Caceres, Antigonorrhoneal activity of plants used in Guatemala for the treatment of sexually transmitted diseases. Journal of Ethanopharma, 48, 1995, Pages 85-88

[36] F. Odutayo, C. Ezeamagu, T. Kabiawu, D. Aina, and G. Mensah-Agyei, Phytochemical Screening and Antimicrobial Activity of Chromolaenaodorata Leaf Extract against Selected Microorganisms. Journal of Advances in Medical and Pharmaceutical Sciences, Vol. 13(4), 2017, Pages 1-9.

[37] K.V. Hridhya, and M. Kulandhaivel, Antimicrobial Activity of Chromolaenaodorata Against Selected Pyogenic Pathogens. International Journal of Pharmacognosy and Phytochemical Research, Vol. 9(7), 2017, Pages 1001-1007. 